\title{
POVERTY, REGIONAL LEGACY IN STRENGTH PRESPECTIVE
}

\author{
Kusuma Wulandari, Sri Wahjuni, Setyowati Karyaningtyas \\ Student of the Welfare Science Doctoral Program at Padjadjaran University, Bandung and \\ Social Welfare Lecturer, Faculty of Social Sciences, Jember University \\ kusuma.wulandari@unej.ac.id \\ Tourism Lecturer, Jember University \\ yuni.adbispar@gmail.com \\ STIA Jember Lecturer \\ tyas.nugroho17@gmail.com
}

\begin{abstract}
Poverty and underdevelopment are two indicators in measuring the level of development of a region. Poverty is one indicator of an area as the lowest category of regions because poverty is defined as a state of the region where people cannot meet basic needs and do not have access to power. Whereas the area left behind is characterized by 1). Low community potential 2). There is no public access to increase its potential. Various efforts to overcome poverty and underdevelopment have been carried out by the government, especially with empowerment. Empowerment is an effort to increase the power of the community in order to have a prosperous life. One of the Empowerment that will be used in overcoming regional backwardness is empowerment based on a community strength approach or Strength Based Perspective.
\end{abstract}

Keywords: Empowerment, Poverty, Legacy and Strength Perspective

\section{Introduction}

Poverty and underdevelopment are a part that is used to measure the success rate of a regional development. Lagging regions can be characterized in several indicators, namely 1). The low of potential and natural resource management, 2) limited access to growth, 3) low socio-economic facilities and infrastructure, 4). The population is scattered and isolated. Some indicators of regional disadvantage are characteristics of the causes of poverty. Poverty is defined as isolation in the physical and psychological sense, meaning that the poor live in remote areas and psychologically. The poor are usually isolated from various information and access, such as access to banking, access to adequate health services, quality education, technological advances, and many other things related to welfare facilities (Chamber, 1987).

Problems related to the development of underdeveloped regions are 1) low quality of human resources, 2). Lack of facilities and infrastructure, 3) limited access to economics, information and technology, 4). There is security and disruption 5). Is a border area, isolated and KAT. Based on the criteria above, Bondowoso District has lagged behind due to Human Resources and Regional Financial Capacity.

Various efforts to overcome regional inadequacies have been carried out among other things with a variety of disadvantaged regional programs focused on social, cultural, economic, regional finance, accessibility and availability of infrastructure. The question is whether the efforts to overcome regional backwardness have succeeded? To 
answer this problem, this paper will discuss related to development approaches in improving community welfare.

\section{Theoretical Framework}

Poverty and Disadvantaged Regions

Poverty is defined as a multi-dimensional problem which means that poverty is not only caused by economic problems but is caused by other problems (Suharto, 2010). Causes of poverty include:

1. Powerlessness. This condition arises because of the lack of employment, the low price of the products they produce, and the high cost of education.

2. Exclusion, low levels of education, lack of expertise, difficulty in transportation, and lack of access to credit caused them to be isolated and poor.

3. Material poverty, this condition is caused by a lack of capital, and the lack of agricultural land owned causes their income to be relatively low.

4. Vulnerability, the difficulty of finding jobs, seasonal work, and natural disasters, making them vulnerable and poor.

5. Attitudes, attitudes that accept what they are and are less motivated to work hard make them poor. (Maipita, 2014)

The underdeveloped area is a district area whose communities and regions are relatively less developed compared to other regions on a national scale (Saifullah, 2006). Related to that, according to Bappenas (2006), an area is categorized as lagging, because: (a) geographically, it is relatively difficult to reach because it is located far inland, hills / mountains, islands, coastal areas and remote islands or because of geomorphological factors others so that it is difficult to reach by a network of both transportation and communication media; (b) in terms of natural resources, has no potential, or has large natural resources, but the surrounding environment is an area that is protected or cannot be exploited, and disadvantaged areas due to excessive exploitation of natural resources; (c) in terms of human resources, generally the people in disadvantaged areas, their level of education, knowledge and skills are relatively low and customary institutions that have not developed; (d) limited infrastructure and facilities for communication, transportation, clean water, irrigation, health, education and other services which cause difficulties in carrying out economic and social activities; (e) often (an area) experiences natural disasters and social conflicts which result in disruption of social and economic development activities; and (f) an area that is lagging behind, caused by some inappropriate policies, such as: not taking the side of development in underdeveloped regions, wrong approaches and development priorities, and not involving indigenous peoples institutions in planning and development.

Approaches in Development

Talking about the problem of poverty and underdevelopment of the region is inseparable from approach-approach in development because the approach in 
development that is used will have an influence on existing changes. Changes related to the success of the development approach used.

The growth approach is a development approach that is oriented towards high economic growth which is assumed that with high economic growth droplets will occur downward but in reality the development results that occur cause new problems such as increasing problems of unemployment and labor, crime rates etc. The development program is top down.

The approach to growth and equity is a development approach that is oriented to the economic, socio-cultural and political assumptions built into this approach is that poverty is not only caused by economic problems but is caused by multidimensional problems. But this approach is the same as the first approach because many development programs designed by those who make policies mean top down.

Basic needs approach, this approach is built on the assumption that basic needs will not be fulfilled if the community is still below the poverty line. In fact, the basic needs approach gives the nature of dependence, meaning that the community cannot establish because the program created is uniform (uniformity) and designed based on the problems faced by the community.

The Independence Approach this approach prioritizes mutually beneficial relationships in development cooperation, relying more on capabilities and own resources.

The above development approach is known as the product center development paradigm, meaning that development policies that are made more in favor of the middle class community only as objects in the development of all decisions are made universally, the people are only consumers rather than producers (Korten \& Klauss, 1984). It turns out that the development approach used by the government has not been able to answer the problem of poverty, which is one of the poverty indicators synonymous with underdeveloped regions.

To realize the desired development change and to overcome underdeveloped areas the government has carried out development with a people center development approach, namely people-centered development that respects and considers local initiatives and differences, prioritizes self-reliance (Nasdian, 2015)

Self-reliance focuses on the relationships between places, communities, and resources that are interwoven into a human ecological system that supports independence at the local level. This development strategy prioritizes local institutions prioritizing the creation of conditions that enable communities in a region and community to meet their own needs and by using local resources that are under the control of the local community. The role of territorial units such as local government is central to the coordination of development policies and the development of local communities.

The people center development paradigm or approach is a development approach that is a people-centered development-oriented approach whose development policy rests on the implementation of principles, decentralization, 
participation, empowerment, conservation, social networking, local wealth and the principle of suability.

The approaches in development used by the government will provide different definitions of looking at poverty. The difference in looking at poverty will make a difference in its handling. That's what happened so far.

Approach in Handling Problems

In handling problems known as problem based deficits, problem handling is focused on efforts to overcome problems or shortcomings so that problem solving is focused on the problem or focused on overcoming problems or deficiencies car ried out during assessment (Ishartono, 2017)

However, in the last decade new perspectives have emerged in handling problems, namely strength perspective. This perspective focuses on the viewers of the problem in terms of existing strengths not on problems or shortcomings. (Ishartono, 2017)

In the context of poverty reduction, a power-based perspective holds that the poor or the poor have the power, have the capacity to develop their lives. . Handling the problem is focused on the utilization of existing forces.

Below this will be explained the difference in problem-based perspective with a power-based perspective :

\begin{tabular}{|l|l|}
\hline Problem based approach & Strength based approach \\
\hline Focus on risk & Focusing on potential \\
\hline Focusing on problems & Focus on strength \\
\hline Intervention & participation \\
\hline There is resistance & There is support \\
\hline Focusing on crisis & $\begin{array}{l}\text { There is understanding and giving } \\
\text { opportunities }\end{array}$ \\
\hline There is a punishment & There is praise or appreciation \\
\hline Control or top down & Empowerment \\
\hline There is a renewal & Adaptation \\
\hline Static & Dynamic \\
\hline Based on orders & Based on community experience \\
\hline $\begin{array}{l}\text { Rigid or in accordance with existing } \\
\text { rules }\end{array}$ & Flexible or follow the rules. \\
\hline
\end{tabular}

Sources: Hammond and Zimmerman

Empowerment

The term empowerment is often used in community development at this time. This concept develops from the state of the individual or society that is helpless or weak (powerless) helpless or has weaknesses in aspects: knowledge, experience, attitude, skills, business capital, networking, enthusiasm, hard work, perseverance and 
other aspects. Weaknesses in this aspect can lead to dependence, helplessness and poverty.

Empowerment is a concept that is related to power. The term power is often synonymous with an individual's ability to make himself or another party do what he wants. The ability is to regulate himself or other parties to do what he wants. Empowerment is a process to give power or power to weak parties and reduce power (disempowered) to parties that are too powerful (poerfull) so that a balance occurs (Djohani, 2003 in Anwas 2014: 49). Empowerment is not just giving authority or power to weak parties. In empowerment the meaning of the educational process is contained in improving the quality of individuals, groups or communities so that they are able to be empowered, have competitiveness, and be able to live independently. According to Ife (1995 in Anwas 2014: 49) empowerment is to prepare the community to strive for resources, opportunities, knowledge and expertise to increase the capacity of the community to determine their future and participate and influence life in the community itself.

The strategy to reduce poverty can be done through strengthening to empower and empowerment activities. Very poor people who have not been able to meet their daily needs and health need to be provided with service programs that can improve their abilities. Handling the problem of poverty cannot be seen only from economic factors but it requires indicators other than economics.

\section{Method}

This type of research is descriptive qualitative, namely a study that wants to know the symptoms or social problems that need to be questioned. This research can be done using the literature exploration method with the results of data obtained from books, research results, journals relating to the theory of poverty and disadvantaged areas, approaches to development, problem handling perspectives and empowerment. As stated by (Idrus.2002: 29) descriptive type of research is used if there is knowledge or information about social symptoms that will be investigated or questioned. This knowledge is obtained from survey literature, research reports, or results from exploration. Analysis using taxonomic analysis is done by grouping domains that have similar themes in one taxonomy. (Idrus.2002: 158).

\section{Results}

Poverty is defined as a multidimensional problem, meaning that poverty is not only caused by economic problems but can also be caused by social problems, political culture. Other causes of fisheries: vulnerability, isolation, helplessness, apathy mental attitude or material poverty while underdeveloped regions are defined as areas that are difficult to reach, lack natural resources and human resources, limitations in access and disasters in the region. Looking at the definitions and causes of these two problems, it can be concluded that in fact the problem of underdeveloped regions is 
one indicator of poverty. The poor are characterized by regions that are left behind as well as the backward regions are identical with poverty. In this definition we do not question whether poverty is a part of underdeveloped regions or a disadvantaged area is characterized by poverty. Just as we analogize eggs first what is chicken first. Therefore in the problem of underdeveloped regions the author is more focused on poverty because one of the characteristics of poverty is underdeveloped regions.

In handling or accelerating the handling of underdeveloped areas various efforts have been made, including: 1). Local economic development, 2). Community Empowerment, 3). Integrated infrastructure development. However, the handling or acceleration of the handling of underdeveloped areas has problems, namely the quality of human resources, lack of facilities and infrastructure and limited access to the economy. Why are efforts to accelerate underdeveloped areas experiencing problems, is there something wrong with the efforts made?

Actually the efforts made by the government in dealing with the problem of underdeveloped regions have used the development approach of the development people center or human-oriented development which is characterized by the existence of community self-reliance oriented to local forces. However, in the assessment or problem solving, the approach used is an approach that is based on a problem approach or perspective deficit so that development programs are made based on existing problems. If the development program of the underdeveloped area or the acceleration of development of underdeveloped areas is based on a strength or perspective strength approach, the program for accelerating underdeveloped areas will be based on the strengths owned by the community.

The capture of disadvantaged areas can be done with community empowerment programs that are based on strengths or potential or assets owned by the community. The main purpose of the strength model is to explore and mobilize the power possessed by the client both from internal sources owned by the client or external sources that exist in the environment around the client. The model that is based on client strength is closely related to the concept of empowerment. Empowerment can be defined as a process of helping individuals, families, groups and communities to enhance personal, interpersonal, siosio-economic and political strengths, and develop influences on improving their environment (Berker in Zastrow in Suharto 2014). This model seeks to identify, use, build and strengthen the strengths and resources that are owned or around the client. This approach emphasizes the client's values, attention, beliefs, sources, achievements and aspirations.

Bondowoso Regency in the analysis of the criteria for regional backwardness is caused by factors of human resources and regional financial capacity. However, this paper will only discuss empowerment as an effort to improve human resources as an effort to accelerate underdeveloped regions.

Empowerment in solving poverty can be done by changing the individual mind set and the community to be empowered and independent. Empowerment can be done 
through various activities that can increase individual and community participation. These types of activities include:

1. Educational and training activities that can encourage skills and skills that are in accordance with the potential and needs of the community.

2. Mentoring activities that can be carried out continuously

3. Grow non-formal institutions in the community

4. Creating various job opportunities

5. Revive local culture and wisdom as social capital

Poverty alleviation activities cannot be carried out independently. There must be support from various parties, including

1. The government acts as the organizer of community empowerment.

2. Members of the legislature act as budget determinants in implementing empowerment in the community.

3. Universities act as innovators and evaluators in implementing empowerment in the community.

4. The business world acts as a donor in the form of CSR for the community in community empowerment.

5. NGOs act as control systems and activists in the implementation of empowerment in the community.

6. Social organizations: as implementers in empowerment

7. Communities as subjects in the implementation of community empowerment.

8. Mass media as a control system in implementing community empowerment.

Educational empowerment

Empowerment in the education sector is directed at changing people's knowledge, attitudes and skills. Empowerment in this aspect starts from analyzing the needs and strengths of the community to improve education. Empowerment in the field of education is done through strengthening the potential that exists in the community by building community awareness about the importance of education. The way of empowerment in the field of education can be done in the form of:

1. Skills training by empowering mothers who deliver school children by providing skills training activities that can improve the family economy. Training that can utilize local potential such as sewing, skills in making food and handicrafts.

2. Through non-formal education such as courses or various skills training, these skills should be adapted to the potential and needs of the local community. For example, in agricultural communities the skills related to agriculture, for example, the skills to match certain types of plants, processing results agricultural product.

3. Stagnation of learning without relying on other people by changing the knowledge of attitudes and abilities without depending on others in accordance with the orientation of each individual tailored to their needs and potential in order to maintain, improve and actualize themselves. 
4. Provision of roles and activities in accordance with the circumstances and selfpotential of individuals who have individual productivity goals to produce finances to meet their life needs

\section{Health Sector Empowerment}

Healthy is very important in human life with a healthy body. We can carry out various activities that have multiple effects, meaning that healthy people can achieve success and happiness. Conversely, if we are sick it is difficult to carry out optimal activities.

Making the community always healthy is not the responsibility of the government alone but is a shared responsibility of both individuals and the community. Many health cases that are still government jobs today are dengue fever, malnutrition, tuberculosis etc. The most appropriate management of health is prevention through community empowerment activities. Potentials in the community are optimized so that they are not attacked by various types of disease, live healthy and happy lives. Various efforts to empower the health sector can be carried out among others:

1. Build awareness of the importance of healthy living in everyday life. These activities can be carried out through socialization in print and electronic media, institutions that exist in the community.

2. Training to community members regarding health volunteers related to first aid.

3. Public awareness for utilizing the yard environment to grow medicinal plants.

4. Giving rewards to the public related to cleaning competitions, health innovations etc.

Empowerment of the small business sector

Micro business or small business is a strong economic power of the people. This business is owned by many people with various businesses both in urban and rural areas besides that this business involves more labor because the production process is almost completely done manually. By involving many workers in this effort is in line with the empowerment indicator. Efforts to empower small businesses can be done through:

1. Growing understanding of potential, excellence and distinctiveness which becomes attractive and competitive product differentiation. The activities carried out can be in the form of workshops related to local potential or local wisdom of the community, assistance activities in small businesses.

2. Encouraging the community to develop various businesses in accordance with their potential. The activities can be in the form of socialization of entrepreneurship, workshops on the growth of entrepreneurial spirit.

3. Development of resilient human resources to create innovations in products that have competitiveness. The activities can be in the form of training related to entrepreneurship, managerial training, finance, and marketing. 
4. Forming a business group or product center based on the type of business to facilitate banking access and cooperation. The activities that can be carried out in the form of assistance by the government in establishing access for microenterprises.

Empowerment of the Agriculture sector

Indonesia is known as an agricultural country. Fertile land with the support of volcanoes which are almost on every island in Indonesia. High rainfall and season support every year make Indonesian land suitable for agricultural businesses, especially Bondowoso Regency. Empowerment of agriculture can be done through:

1. Changing the behavior of farmers, farmers are encouraged to have competitiveness and independence. Activities can be carried out through workshops related to mindset changes and behavior for farmers.

2. Empowerment starting from the production, maintenance, harvest, postharvest and marketing processes. Training activity in agribusiness / agricultural businesses.

3. Empowerment of various methods according to the problems experienced by farmers. These activities can be carried out through farmer courses, training, demonstrating of the results of agricultural innovations.

4. Training to understand local wisdom related to the natural conditions of the future.

5. Planting innovative soul activities that are planned through mentoring, skills and training related to modification of agricultural tools, use of organic fertilizers etc.

6. Formation of farmer groups, building partnership activities that can be done through mentoring.

Based on the concepts that have been described, the relationship between the development approach, the problem approach, poverty, underdeveloped areas and empowerment will be described as follows:

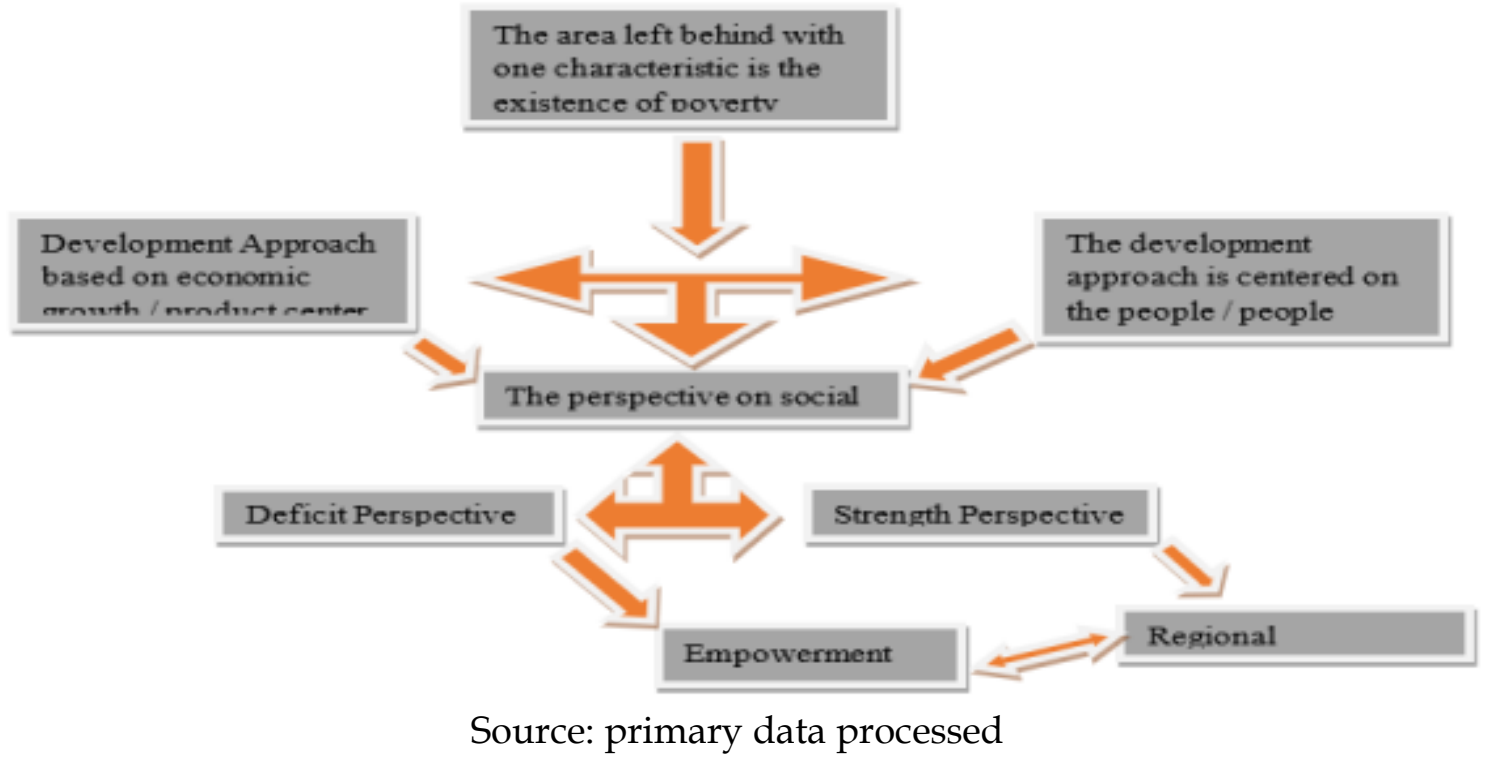




\section{Conclusion}

The problem of underdeveloped areas is not a failure in the development approach but is a mistake in the perspective of defining existing problems. In this case the approach to defining the problem can be seen from the deficit approach and the power approach. If the approach to social problems is seen from the perspective of strength, the problems related to underdeveloped regions are unlikely to arise because to overcome the existing problems based on the strength that exists in the community, not from the shortcomings that exist.

\section{References}

Anwas, Oos M. (2013). "Pemberdayaan Masyarakat di Era Global". Bandung; Alfabeta

Bappenas. 2006. Seminar Nasional Percepatan Pembangunan Sosial Ekonomi Daerah

Tertinggal. Dit. Kawasan Khusus dan Daerah Tertinggal.

Chamber Robert.1987. Pembangunan dari Belakang. Jakarta:LP3S

Hammond Wayne, 2010. Principle of Strength-Based Practice. https:// www. Esd .ca/ programs/ resiliency/documents/ rsl_strength_based_perspective.pdf.

Ishartono. 2017.Kajian Kemiskinan dari Perspektif Kekuatan.Bandung: Unpad Press

Idrus, Muhammad. Metode Penelitian Ilmu Sosial Pendekatan Kualitatif dan Kuantitatif .Jakarta: Erlangga. 2009.

Laporan Rencana Aksi Pembangunan daerah tertinggal Kabupaten Bondowoso tahun 2017.

Muhtar dkk, Masyarakat Desa Tertinggal: Kebutuhan, Permasalahan, Aset, dan Konsep

Model

Pemberdayaannya.https://media.neliti.com/media/publications/52991-IDsumber-daya-dan-permasalahan-sosial-di-d.pdf.

Maipita Indra.2014. Mengukur Kemiskinan dan Distribusi Pendapatan.Yogyakarta: UPP STIM YKPN.

Nasdian Tonny Fredian.2015. Pengembangan Masyarakat.Jakarta: Yayasan Pustaka Obor Indonesia.

Soetomo.2015.Pemberdayaan Masyarakat. Yogyakarta: Pustaka Pelajar.

Suharto Edi.2013. Kemiskinan Perlindungan dan Sosial di Indonesia Menggagas Model Jaminan Sosial Universal Bidang Kesehatan.Bandung: Alfabeta 